\title{
Perbedaan Adversity Quotient dan Kematangan Emosi Remaja SMP ditinjau dari Jenis Kelamin
}

\section{The Difference of Adversity quotient and Emotional Maturity of Youth based on Sex}

\author{
Ayub Djafar, IGAA Noviekayati, Sahat Saragih \\ Magister Psikologi Profesi Fakultas Psikologi \\ Universitas 17 Agustus 1945 Surabaya \\ ayub.djmado@gmail.com
}

KATA KUNCI

KEYWORDS

ABSTRAK
ABSTRACT adversity quotient, kematangan emosi, remaja SMP

adversity quotient, emotional maturity, gender, junior high school

Untuk menghadapi permasalahan yang dihadapi dalam kehidupan remaja dibutuhkan adversity quotient (daya juang). Adversity quotient merupakan pemahaman penting tentang apa yang dibutuhkan remaja untuk mencapai kesuksesan yakni kemampuan untuk bertahan dan menghadapi kesulitan disetiap masalah yang ada. Kemampuan ini hanya akan dimiliki individu yang memiliki kemampuan untuk memegang kendali dan merespon suatu kesulitan atau tekanan secara positif. Selain itu diperlukan juga kematangan emosi sehingga remaja mencapai tingkat perkembangan emosional dan tidak lagi menampilkan pola emosi yang kekanak-kanakan. Remaja yang matang memiliki perkembangan sistem nilai yang baik, konsep diri yang tepat dan memiliki perilaku emosional yang stabil. Tujuan penelitian ini adalah untuk mengetahui perbedaan adversity quotient dan kematangan emosi remaja SMP di tinjau dari jenis kelamin, hubungan antara adversity quotient dan kematangan emosi remaja SMP, dan perbedaan kematangan emosi dan adversity quotient remaja SMP di Kota Kendari. Populasi dalam penelitian ini adalah seluruh siswa-siswi remaja SMP yang ada di Kota Kendari dengan sampel berjumlah 150 orang siswa-siswi SMP di Kota Kendari. Instrument penelitian adalah skala adversity dan skala kematangan emosi. Hasil dari analisis kuantitatif dengan Uji t-Test membuktikan bahwa, tidak terdapat perbedaan adversity quotient dan kematangan emosi remaja SMP ditinjau dari jenis kelamin $(p=0.747>0.05)$, nilai $t$ $=0.110$. Hasil analisis kuantitatif dengan uji korelasi pearson, membuktikan terdapat hubungan antara adversity quotient dan kematangan emosi remaja SMP di Kota kendari $(p=0.046<0.05)$. Selanjutnya ditemukan pula tidak terdapat perbedaan antara kematangan emosi Remaja SMP berjenis kelamin laki-laki dan perempuan. $(p=0.435$ $>0.05)$ t hitung $=1.544$.

To face the problems faced in adolescent life required adversity quotient (fighting power). Adversity quotient is an important understanding of what teenagers need to achieve success that is the ability to survive and face difficulties in every problem. This ability will only be owned by individuals who have the ability to take control and respond to a difficulty or pressure positively. In addition it also needs emotional maturity so that 
teenagers reach the level of emotional development and no longer display the childish emotional patterns. A mature teenager develops a good value system, proper self-concept and has stable emotional behavior. The purpose of this research is to know the difference of adversity quotient and emotional maturity of junior high school adolescent in terms of gender, relationship between adversity quotient and emotional maturity of junior high school, and difference of emotional maturity and adversity quotient of junior high school in Kendari. The population in this study were all junior high school students in Kendari City and the sample in this study amounted to 150 students of junior high school in Kendari. The research instrument is the scale of adversity and the scale of emotional maturity. The result of quantitative analysis with $t$-Test proves that there is no difference adversity quotient and emotional maturity of junior high school teenagers $(p=0.747>0.05) t=0.110$. The result of quantitative analysis with Pearson correlation test proves that there is a relationship between adversity quotient and emotional maturity of junior high school in Kendari $(p=0.046<0.05)$. And there is no difference between the emotional maturity of junior high school male and female sex. ( $p=$ $0.435>0.05)$ t arithmetic $=1.544$.

\section{PENDAHULUAN}

Masa remaja merupakan salah satu fase dari perkembangan individu. Masa remaja memiliki ciri yang berbeda dengan masa sebelum atau sesudahnya, sehingga masa remaja menjadi menarik untuk dibicarakan. Masa remaja seringkali dihubungkan dengan mitos dan stereotip mengenai penyimpangan dan ketidakwajaran. Hal tersebut dapat dilihat dari banyaknya teori-teori perkembangan yang membahas ketidakselarasan, gangguan emosi dan gangguan perilaku sebagi akibat dari tekanan-tekanan yang dialami remaja pada dirinya maupun akibat perubahan lingkungan (Darajat,1995).

Sejalan dengan dengan perkembangan remaja yang begitu pesat, remaja juga mengalami berbagai hambatan dan masalah dalam kehidupannya. Terdapat empat permasalahan utama yang sering dihadapi oleh sebagian besar remaja, yaitu penggunaan obat-obat terlarang, kenakalan remaja, permasalahan seks, dan masalah yang ada disekolah (Dryfoos \& Barkin, dalam Santrock, 2010). Pengaruh lingkungan pada tahap yang pertama diawali dengan pergaulan teman sebaya. Sebagian besar waktu_individu dihabiskan untuk berhubungan atau bergaul dengan teman sebaya.

Menurut Santrock (2003) peranan kelompok teman sebaya bagi individu adalah memberikan kesempatan untuk belajar tentang bagaimana berinteraksi dengan orang lain, pakar mengontrol tingkah laku sosial, mengembangkan minat yang relevan dengan usiannya, saling bertukar perasaan dan masalah. Walaupun kelompok teman sebaya mempunyai kontribusi yang positif terhadap perkembangan individu, namun di sisi lain, tidak sedikit individu yang berperilaku menyimpang akibat dari pengaruh teman sebaya. Sementara itu, Sarwono (2005) mengatakan bahwa kuatnya pengaruh teman sebaya sering dianggap sebagai biang keladi dari tingkah laku individu yang buruk. Akan tetapi, pada hakikatnya faktor terakhir yang menentukan bagaimana tindakan individu adalah individu itu sendiri. 
Salah satu tugas perkembangan remaja adalah memiliki tanggung jawab menyesuaikan dirinya terhadap nilai-nilai yang ada di sekolah dan lingkungan masyarakat. Pada kenyataannya, masih banyak remaja yang melakukan tindakan yang bertentangan dengan aturan yang ada di sekolah dan masyarakat, sehingga seringkali dianggap melakukan kenakalan. Salah satu bentuk kenakalan remaja adalah mencoba menggunakan obat-obatan terlarang (narkoba). Pendidikan merupakan salah satu pihak yang berkewajiban dan bertanggung jawab dalam upaya pencegahan penyalahgunaan narkoba dikalangan remaja. Karena remaja merupakan objek yang secara emosional masih labil, sehingga sangat rentan untuk menggunakan obat-obatan terlarang (narkoba). Mulai dari rasa ingin tahu, mau mencoba-coba, ikut-ikutan teman, rasa solidaritas grup yang kuat dan memilih lingkungan yang salah sampai dengan faktor keluarga yang kurang perhatian dan lain sebagainya.

Masalah penyalahgunaan narkoba di Indonesia, sekarang ini sudah sangat memprihatinkan. Hal ini disebabkan oleh beberapa hal antara lain karena Indonesia yang terletak pada posisi di antara tiga benua dan mengingat perkembangan ilmu pengetahuan dan teknologi, maka pengaruh globalisasi, arus transportasi yang sangat maju dan pergeseran gelap narkoba. Masyarakat Indonesia bahkan masyarakat Kota Kendari khususnya saat ini sedang dihadapkan pada keadaan yang sangat mengkhawatirkan akibat maraknya pemakaian secara ilegal jenis obat Paracetamol Caffein Carisoprodol (PCC) (obat yang diduga jenis narkoba). Kekhawatiran ini semakin di pertajam akibat maraknya peredaran gelap parkoba jenis Paracetamol Caffein Carisoprodol (PCC) yang telah merebak di lapisan masyarakat khusunya kalangan remaja di Kota Kendari, seperti fakta yang terjadi beberapa waktu lalu di Kota Kendari, beberapa remaja mengalami kejangkejang, merasa melayang dan mengamuk dan tidak sadarkan diri (Kendari Pos, 16/09/2017).

Berdasarkan informasi yang diperoleh dari salah satu karyawan Rumah Sakit Jiwa Kendari (Wawancara Personal, 18/09/2017), tercatat sekitar \pm 50 orang remaja yang dilarikan ke Rumah Sakit Jiwa Kendari untuk mendapatkan pertolongan akibat penyalahgunaan obat Paracetamol Caffein Carisoprodol (PCC). Bahkan ada seorang siswa sekolah dasar yang meninggal akibat mengkonsumsi obat jenis PCC' (Paracetamol Caffein Carisoprodol). Berdasarkan informasi yang diperoleh, dari beberapa korban yang tercatat lebih banyak remaja laki-laki dari pada perempuan. Para korban penyalahgunaan obat PCC merupakan pihak yang sangat membutuhkan pertolongan, tidak hanya pertolongan dari bidang medis, melainkan juga dukungan moral semua pihak, baik dari keluarga, teman maupun lingkungan tempat tinggal mereka.

Remaja yang merupakan korban penyalahgunaan dan peredaran gelap narkotika disebut akan mendapatkan stigma negatif dari masyarakat, terlebih lagi apabila mereka sampai kecanduan menderita penyakit gangguan psikis akibat penyalahgunaan obat-obatan terlarang (narkoba). Untuk membantu pemulihan remaja korban penyalahgunaan narkoba, sangat diperlukan dukungan keluarga, seperti ayah, ibu, saudara, istri, suami, pacar dan Panjang keluarga dekat lainnya. Sebaiknya anggota keluarga mempunyai rasa tanggung jawab yang tinggi terhadap pemulihan klien. Dampaknya adalah tumbuh rasa aman, rasa percaya diri dan rasa tanggung jawab klien terhadap diri dan keluarga (Willis, 2010).

Santrock (2003) mengatakan bahwa kebanyakan anak dan remaja pada suatu waktu akan melakukan hal-hal yang merusak atau mengakibatkan munculnya kesulitan bagi dirinya sendiri atau orang lain. Bila tingkah laku demikian membuat individu melakukan banyak tindakan ilegal maka masyarakat menganggap individu 
tersebut sebagai pelaku kenakalan (delinquent). Pada masa remaja, individu menghadapi tuntutan dan harapan, demikian juga bahaya dan godaan, yang tampaknya lebih banyak dan kompleks dibandingkan dengan individu pada generasi yang lalu.

Transisi dari masa anak ke masa dewasa merupakan masa perkembangan fisik, kognitif dan sosial yang memberikan tantangan, kesempatan dan pertumbuhan. Meskipun individu pada masa remaja mengalami transisi dari masa anak ke masa dewasa dengan lebih positif, namun banyak juga individu yang tidak cukup memperoleh kesempatan dan dukungan untuk menjadi dewasa yang kompeten. Dalam banyak hal, individu dihadapkan pada lingkungan yang tidak stabil, perceraian orang tua serta bertambahnya mobilitas tempat tinggal keluarga menyebabkan kurangnya stabilitas dalam kehidupan individu. Individu pada kelompok ini lebih mudah terlibat pada kegiatankegiatan yang negatif, seperti penyalahgunaan obat dan alkohol atau kenakalan. Banyak pula di antara individu pada kelompok ini yang mengalami ketidakstabilan emosi (Santrock, 2003).

Dalam menghadapi kemajuan jaman yang semakin pesat seperti sekarang ini, maka individu perlu dipersiapkan menjadi pribadi yang matang baik jasmani maupun rohaninya. Di dalam proses mencapai kematangan tersebut individu memerlukan bimbingan dari orang tua dan orang dewasa di lingkungan sekitar. Hal tersebut karena individu belum cukup memiliki pemahaman atau wawasan tentang dirinya dan lingkungannya, juga pengalaman dalam menentukan arah hidupnya. Mencapai suatu kematangan merupakan tugas perkembangan individu di masa remaja, salah satunya adalah mencapai kematangan emosional. Menurut Turner dan Helms (1995) kematangan mengarah pada tahapan untuk meningkatkan fisik dan psikis menjadi lebih baik. Individu yang matang memiliki perkembangan sistem nilai yang baik, konsep diri yang tepat dan memiliki perilaku emosional yang stabil.

Schneiders (1964) mengatakan bahwa individu disebut matang emosinya jika potensi yang dikembangkan dapat ditempatkan dalam suatu kondisi pertumbuhan. Tuntutan yang nyata dari kehidupan individu dapat dihadapi dengan cara efektif dan positif. Seseorang memiliki tingkat kematangan emosional tinggi, berarti individu mampu mengendalikan dorongan emosinya, pandai membaca perasaan orang lain serta memelihara hubungan baik dengan lingkungannya.

Untuk mengatasi permasalahan yang dihadapi dibutuhkan Adversity quotient (daya juang) pada remaja SMP. Adversity quotient atau kecerdasan adversitas merupakan pemahaman penting tentang apa yang dibutuhkan untuk mencapai kesuksesan. Sukses tidaknya individu dalam kehidupan ditentukan oleh kecerdasan adversitas, dimana kecerdasan adversitas dapat memberitahukan sejauhmana individu mampu bertahan dan mengatasi kesulitan yang dihadapi, individu mana yang mampu mengatasi kesulitan dan yang tidak mampu, individu mana yang akan memenuhi harapan dan potensi serta yang akan gagal, individu yang akan menyerah dan yang akan bertahan (Stoltz, 2000).

Menurut Stoltz (2000) setiap individu memiliki adversity quotient yang tinggi dan rendah. Adapun karakteristik individu yang memiliki adversity quotient tinggi, antara lain optimis, gigih, dan ulet dalam menghadapi masalah, berpikir dan bertindak secara matang dan bijaksana, dapat memotivasi diri sendiri, berani mengambil resiko dalam menghadapi tantangan dan perubahan hidup, bekerja dengan semangat tinggi, berorientasi pada masa depan dan memiliki komitmen untuk maju, disiplin, mengatakan hal-hal yang optimis dalam menghadapi masalah.

Stoltz (2000) juga mengungkapkan karakteristik individu yang memiliki adversity quotient rendah, yaitu pesimis dan 
mudah frustrasi dalam menghadapi masalah, berpikir dan bertindak cenderung tidak kreatif dan tidak berani mengambil resiko, atau menyalahkan orang lain sebagai penyebab suatu masalah atau kesulitan, cenderung lari dari masalah yang dihadapi, bekerja dengan tidak semangat dan tidak ambisius, cenderung emosional dalam melakukan pekerjaan, tidak berorientasi pada masa depan dan menghindari tantangan, mengatakan hal-hal yang pesimis dalam menghadapi masalah.

\section{METODE PENELITIAN}

\section{Partisipan Penelitian}

Populasi Penelitian ini adalah remaja di Kendari. Penentuan sampel dalam penelitian ini menggunakan teknik purposive sampling yaitu pengambilan sampel yang didasarkan atas tujuan tertentu dari populasi yang telah diketahui ciri dan sifatnya (Arikunto, 2002). Keterbatasan waktu dan tenaga adalah alasan digunakannya teknik pengambilan sampel ini. sampel yang memiliki karakteristik tertentu yang dapat menjawab permasalahan penelitian. Jumlah sampel yang digunakan dalam penelitian ini adalah berjumlah 150 orang remaja smp laki-laki dan perempuan yang ada di Kota Kendari yang terdiri dari 75 Orang remaja laki-laki dan 75 orang remaja perempuan.

\section{Hipotesis Penelitian}

1. Terdapat perbedaan tingkat adversity quotient antara partisipan penelitian remaja laki-laki dengan perempuan di Kota Kendari.

2. Terdapat hubungan antara tingkat adversity quotient dengan tingkat pada partisipan penelitian remaja laki-laki dengan perempuan.

3. Terdapat perbedaan tingkat kematangan emosi antara partispan penelitian remaja laki-laki dan remaja perempuan.

\section{Instrumen Penelitian}

Alat ukur penelitian ini menggunakan model skala Likert yang sudah dimodifikasi dengan pernyataan-pernyataan lewat 4 alternatif pilihan jawaban, yaitu : Sangat Setuju (SS), Setuju (S), Tidak Setuju (TS), dan Sangat Tidak Setuju (STS). Skala yang dipergunakan berisi pernyataan-pernyataan yang mendukung variabel yang akan diungkap (favourable) dan pernyataanpernyataan yang tidak mendukung variabel yang hendak diungkap (unfavourable) dan setiap pernyataan diberi nilai. Pemberian nilai untuk pernyataan favourable bergerak dari 4 sampai 1. Bila jawaban sangat setuju nilainya 4 , setuju nilainya 3 , tidak setuju nilainya 2 , dan sangat tidak setuju nilainya 1. Pernyataan unfavourable nilainya bergerak dari 1 sampai 4. Bila jawaban sangat setuju nilainya 1 , setuju nilainya 2 , tidak setuju nilainya 3 , dan sangat tidak setuju nilainya 4. Pernyataan-pernyataan dalam skala ini dibuat berdasarkan teoriteori pendukung yang dianggap mewakili indikator variabel penelitian.

Untuk mengukur kematangan emosi digunakan skala kematangan emosi yang disusun berdasarkan komponen-komponen utama dan prinsip-prinsip dasar dari kecerdasan emosional. Kematangan Emosi didefinisikan oleh Salovey (1997) sebagai kemampuan seseorang untuk mengenali emosi diri, kemampuan mengelola emosi, kemampuan memotivasi diri sendiri, kemampuan mengenali emosi orang lain (empati) dan kemampuan untuk membina hubungan (kerjasama) dengan orang lain. Skala ini terdiri dari 33 pernyataan.Setelah melalui proses uji coba, koefisien reliabilitas Cronbach's Alpha yang diperoleh adalah 0,899.

Skala Adversity quotient digunakan untuk mengukur tingkat adversity quotient remaja SMP. Skala ini disusun berdasarkan definisi konseptual Adversity quotient yang dikemukakan oleh Stoltz (2005) yakni skala ini terdiri lima aspek yaitu control, origin, ownership, reach, dan endurance (disingkat CO2RE) (Stoltz, 2005). Skala ini terdiri dari 16 pernyataan setelah melalui proses 
uji coba, koefisien reliabilitas Cronbach's Alpha yang diperoleh adalah 0,807.

\section{Teknik Analisa Statistik}

Hipotesis dalam penelitian ini diuji dengan menggunakan teknik statistik Uji-t atau t-Test.

\section{ANALISIS \& HASIL}

\section{Uji Normalitas}

Hasil analisis One-Sample Kolmogrof-Smirnov Test terhadap skor yang diperoleh skala Adversity quotient menunjukkan nilai $\mathrm{Z}$ yang diperoleh = 1.369 dan $\mathrm{p}=0.047$ ( $\mathrm{p}<0.05)$. Dengan demikian, data berdistribusi normal. Hasil analisis One-Sample Kolmogrof-Smirnov Test terhadap skala kematangan emosi menunjukkan nilai $\mathrm{Z}$ yang diperoleh = 0.892 dan $p=0.404$ ( $>>0.05)$. Dengan demikian, data berdistribusi normal.

\section{Uji homogenitas}

Hasil uji homogenitas variansi variabel adversity quotient dengan Levene's Test for Equality of Variances menghasilkan nilai $\mathrm{F}=0.105$ dan $\mathrm{p}=0.747$ ( $\mathrm{p}>0.05$ ). Artinya, tidak ada perbedaan variansi Adversity quotient pada remaja laki-laki dan perempuan. Sementara itu hasil uji homogenitas variansi variabel kematangan emosi menghasilkan nilai $\mathrm{F}=$ 0.614 dan $\mathrm{p}=0.435(\mathrm{p}>0.05)$ variansi homogen. Dengan demikian tidak ada perbedaan variansi kematangan emosi pada remaja laki-laki dan perempuan.

\section{Uji Hipotesis}

Berdasarkan hasil uji t-Test untuk mengetahui perbedaan adversity quotient dan kematangan emosi ditinjau dari jenis kelamin, diperoleh nilai $\mathrm{t}=0.110$ dan $\mathrm{p}=0.747 \quad(\mathrm{p}>$ 0.05). Temuan ini menunjukkan tidak ada perbedaan adversity quotient dan kematangan emosi antara remaja laki-laki dan perempuan yang signifikan.

Berdasarkan hasil uji korelasi dengan menggunakan pearson product moment, diperoleh nilai signifikansi (2-tailed) sebesar $0.046 \quad(\mathrm{p}<0.05)$. Temuan ini menunjukkan bahwa terdapat hubungan yang signifikan antara variabel adversity quotient dan variabel kematangan emosi.(r $=-, 163)$.

Berdasarkan hasil analisis uji t-Tes, untuk mengetahui perbedaan antara kematangan emosi kelompok remaja lakilaki dengan kelompok remaja perempuan diperoleh $\mathrm{t}$ hitung $=1.544$ dan $\mathrm{p}=0.435(\mathrm{p}$ $>0.05)$. Temuan ini menunjukkan tidak terdapat perbedaan kematangan emosi antara remaja laki-laki dan perempuan.

\section{DISKUSI}

Berdasarkan perhitungan hasil analisis data untuk uji hipotesis pertama diperoleh hasil bahwa tidak terdapat perbedaan tingkat adversity quotient antara partisipan penelitian remaja laki-laki dengan remaja perempuan. Demikian pula tidak terdapat perbedaan tingkat kematangart emosi antara partisipan penelitian remaja laki-laki dengan remaja perempuan.Ditolaknya hipotesis pertama dalam penelitian ini memberi arti bahwa jenis kelamin, tidak memberikan perbedaan pada tingkat adversity quotient dan tingkat kematangan emosi pada remaja SMP (Sekolah Menengah Pertama). Hal ini berarti remaja laki-laki dan remaja perempuan memiliki adversity quotient (daya juang) dan kematangan emosi yang sama baik.

Hasil analisis data untuk menguji hipotesis kedua menunjukkan terdapat hubungan yang signifikan antara adversity quotient dengan kematangan emosi. Artinya dalam mengahadapi suatu permasalahan yang ditemui dalam kehidupan sehari-hari, remaja membutuhkan kemampuan untuk bertahan dan menghadapi kesulitan disetiap masalah yang ada. Kemampuan ini hanya akan dimiliki individu yang memiliki kemampuan untuk memegang kendali dan merespon suatu kesulitan atau tekanan secara positif, disinilah peran adversity quotient yang dibutuhkan remaja untuk 
menghadapi tekanan. Selain itu remaja memerlukan emosi yang matang dalam menghadapi hambatan dan kesulitan yang ada untuk itulah dibutuhkan kematangan emosi. Kematangan emosi sangat berperan dalam menahan luapan emosi remaja saat mengahadapi masalah dan meluapkan emosinya pada saat yang tepat.

Hasil analisis data untuk menguji hipotesis ketiga menunjukkan tidak terdapat perbedaan tingkat kematangan emosi antara remaja laki-laki dan perempuan. Artinya kematangan emosi remaja SMP (Sekolah Menengah Pertama) yang berjenis kelamin laki-laki dengan perempuan tidak terdapat perbedaan yang signifikan. Kematangan emosi yang memadai dapat membantu remaja mencapai adversity quotient (daya juang) yang baik yaitu dimana remaja SMP (Sekolah Menengah Pertama) mampu dalam menahan tekanan emosi karena kematangan emosi membuat individu dapat menyeleksi tempat dan waktu yang tepat untuk mengungkapkan tekanan emosinya dalam bentuk yang wajar dan dapat diterima oleh orang lain, karena individu dapat beradaptasi dan bertahan dengan perubahan yang terjadi dilingkungan keluarganya.

\section{SIMPULAN}

Berdasarkan hasil analisis data yang diperoleh serta pengujian hipotesis, maka dapat disimpulkan bahwa:

1. Tidak ada perbedaan' tingkat adversity quotient antara partisipan penelitian remaja laki-laki dengan perempuan di Kota Kendari.

2. Ada hubungan antara tingkat adversity quotient dengan tingkat pada partisipan penelitian remaja laki-laki dengan perempuan di Kota Kendari.

3. Tidak ada perbedaan tingkat kematangan emosi antara partispan penelitian remaja laki-laki dan remaja perempuan di Kota Kendari.

\section{SARAN}

1. Bagi Remaja
Remaja SMP (Sekolah Menengah Pertama) diharapkan dapat mengelola emosinya secara matang dan mengekspresikan emosinya dengan baik agar dapat menghadapi setiap masalah yang ada dengan tenang dan terhindar dari pergaulan yang salah. Remaja SMP (Sekolah Menengah Pertama) hendaknya terus mengembangkan pot kemampuannya dalam menjalani pergaulan dilingkungan sekolah dan lingkungan masyarakat, agar terbiasa menghadapi kesulitan dan masalah yang ada dalam lingkungan masyarakat dan sekolah.

2. Bagi Orang Tua dan Tenaga Pendidik (Guru)

Orang tua dan Tenaga pendidik (Guru) diharapkan lebih memperhatikan perkembangan adversity quotient dan kematangan emosi remaja. Agar remaja mampu mempersiapkan diri dalam beradaptasi dengan lingkungan masyarakat.

3. Bagi Peneliti Lain

Peneliti lain diharapkan lebih memperluas ruang lingkup penelitian atau populasi, sehingga diharapkan dapat meningkatkan kuaitas penelitian, agar penelitian selanjutnya lebih komprehensif. Selain itu perlu menggunakan sumber data tambahan melalui wawancara atau observasi, agar hasil penelitian yang didapatkan lebih mendalam, karena tidak semua hal dapat diungkap dengan skala psikologi.

\section{DAFTAR PUSTAKA}

Achmad, J.N. (2011). Dinamika Perkembangan Anak dan Remaja : Tinjauan Psikologi, Pendidikan dan Bimbingan. Bandung : PT. Refika Aditama.

Arikunto, S. (2006). Prosedur Penelitian. Jakarta : Rhineka Cipta

Aziz, R. (1999). Hubungan antara kecerdasan emosional dan 
penyesuaian diri dengan kecenderungan berperilaku delinkuen pada remaja. Tesis, Yogyakarta : Universitas Gadjah Mada.

Azwar, S. (2012). Metode Penelitian. Yogyakarta : Pustaka Pelajar. (2012). Reliabilitas dan Validitas. Yogyakarta : PT. Pustaka Pelajar.

Daradjat, Zakiyah. (1995). Remaja Harapan Dan Tantangan. Jakarta : Ruhama.

(1983). Pembinaan Remaja. Jakarta : Bulan Bintang. .(1983). Kesehatan Mental. Jakarta : Gunung Agung.

Goleman, D. (1995). Kecerdasan Emosional: Mengapa EQ lebih penting daripada 10 (Terjemahan). Jakarta: Gramedika Pustaka Utama.

\section{- (2000). Kecerdasan Emosional. Jakarta: Gramedia Pustaka Utama.}

Salovey, P., \& Sluyter, D.J. (1997). Emotional development and emotional intelegence. New York: Basic Books.

Santrock, J.W. (2002). Life-span Development : Perkembangan Masa Hidup. Edisi 5 jilid 2. Jakarta: Erlangga.

(2003). Adolescence. Perkembangan Remaja. Edisi Keenam. Jakarta : Erlangga - (2010). Remaja (Edisi Kesebelas). Jakarta : Erlangga

$$
\text { (2012). Life-span }
$$
Development 13 th Edition University of Texas. NY: Mc Graw-Hill.

Sarwono, S.W. (1989). Psikologi Remaja. Jakarta: Raja Grafindo Persada (2010). Psikologi Remaja. Jakarta : Rajawali Pers.
Schneider, A.A. (1964). Personal Adjusment and Mental Health. New York: Holt, Rinehart and Winston.

Stoltz. G.P. (1997). Adversity quotient. Turning Obstacle into Opportunities. New Jersey: John Wiley \& Sons,inc. (2000). Adversity quotient : Mengubah Hambatan Menjadi Peluang. Alih Bahasa: T. Hermaya. Jakarta: PT. Grasindo. (2003). Adversity quotient at Work. Batam: Interaksara. (2005). Adversity quotient: Mengubah Hambatan Menjadi Peluang. Terj. : T. Hermaya; Ed. : Yovita Hardiwati). Jakarta: PT. Grasindo.

. (2008). Adversity Advantage Mengubah Masalah menjadi Berkah. Jakarta: Gramedia.

Willis, S.S. (1991). Remaja dan Masalahnya. Bandung: Alfabeta. (1994). Problema Remaja dan Pemecahannya. Bandung: Angkasa. (2010). Remaja \& Masalahnya. Bandung: Alfabeta.

Winarsunu, T. (2012). Statistik dalam Penelitian Psikologi Pendidikan. Malang: UMM Press. 